https://doi.org/10.15407/ujpe63.5.379

A.V. KULINICH, ${ }^{1}$ A.A. ISHCHENKO, ${ }^{1}$ L.F. SHARANDA,${ }^{2}$ S.V. SHULGA,${ }^{2}$ V.M. OGENKO ${ }^{2}$

${ }^{1}$ Institute of Organic Chemistry, Nat. Acad. Sci of Ukraine (5, Murmans'ka Str., Kyiv, Ukraine, 02660; e-mail: andrii.kulinich@gmail.com)

${ }^{2}$ V.I. Vernadsky Institute of General and Inorganic Chemistry, Nat. Acad. Sci. of Ukraine (32-34, Acad. Palladin Ave., 03680, Kyiv, Ukraine)

\title{
SORPTION OF POLYMETHINE DYES ON NANOGRAPHITES AND CARBON NANOTUBES ${ }^{1}$
}

\begin{abstract}
The sorption of functional molecules is a simple rather effective way of modification of nanostructures. The goal of this work is to study the sorption of various polymethine dyes on nanographites and carbon nanotubes. A simple technique affording the preparation of macroscopic amounts (tens of grams) of nanographite from an available starting material has been implemented. The chemical functionalization of the obtained nanographite has been carried out in order to modify its binding properties. Stable suspensions of nanographite and its modifications are obtained in water and organic solvents. It is found that the cationic, anionic and neutral (merocyanine) polymethine dyes do not bind efficiently with the surface of the studied nanographites. Carbon nanotubes of different types (single-, double-, and multiwall) under the same conditions form stable associates with polymethine dyes, what is primarily manifested by a decrease in the absorption intensity of dyes in time, as well as by the additional stabilization of the nanotube suspension. The DFT calculations demonstrate that the studied dyes do not bind strongly, indeed, with nanographites, but they can form more stable aggregates with carbon nanotubes.

Keywords: functional dyes, nanographite, carbon nanotubes, DFT.
\end{abstract}

\section{Introduction}

Carbon nanostructures due to their numerous possible applications, including functional materials and organic electronics, are an increasingly expanding research subject, whose foundation was laid about 40 years ago by the discovery of fullerenes and carbon nanotubes. The revealing of unique properties of graphene [1], as well as the improvements of methods of synthesis and a modification of fullerenes and nanotubes $[2,3]$, contributed to a further growth of studies in this field. For example, the novel composites from electrically conductive polymers, nanotubes,

(c) A.V. KULINICH, A.A. ISHCHENKO, L.F. SHARANDA, S.V. SHULGA, V.M. OGENKO, 2018

ISSN 2071-0194. Ukr. J. Phys. 2018. Vol. 63, No. 5 and graphene oxides promising for photovoltaics and large capacity photoconductors have been created [4], although high prices constrain their actual practical implementation. That is why nanographites (NGs) multilayered graphene clusters - attract such interest in these days. Due to the comparative cheapness and possibilities for a chemical modification, they are presently the most available carbon nanostructures, being potential matrices for creating the materials with unusual optical, electric, and magnetic properties [5]. The highly developed surface of these nanomaterials allows the adjustment of their

1 The paper was presented at the XXIII Galyna Puchkovska International School-Seminar "Spectroscopy of Molecules and Crystals". 


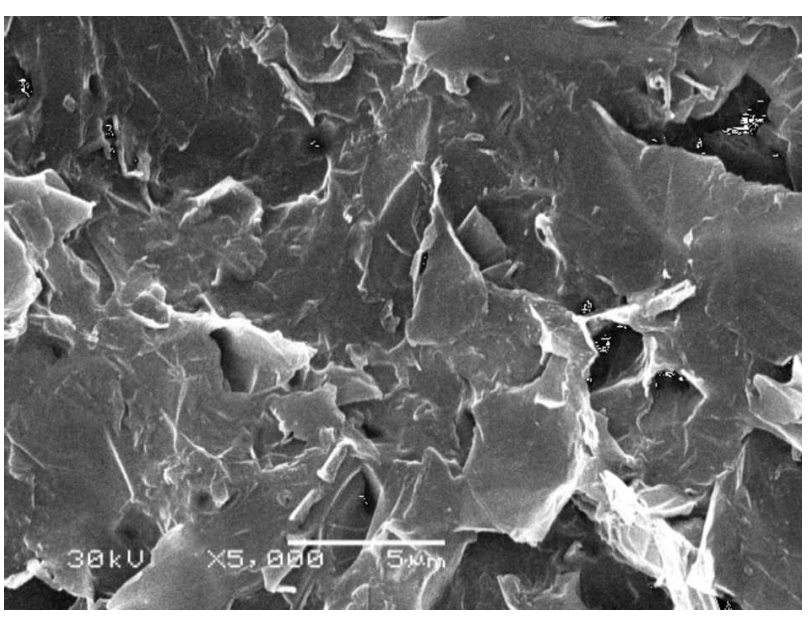

Fig. 1. Electronic microphography (a high-resolution transmission microscope JEOL-200) of the obtained dispersed NG. Separate few-layer graphene "stacks" with linear dimensions of 5-20 nm can be seen<smiles>N#CC(C#N)=CC=CC=CC(C#N)C#N</smiles>

1
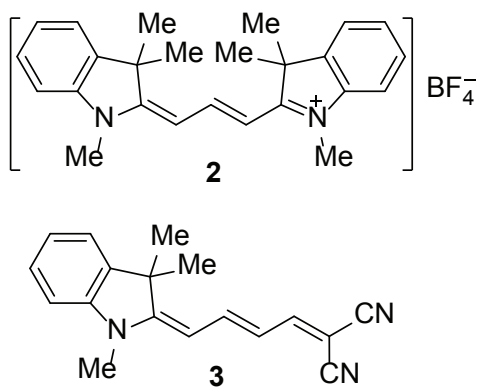

Fig. 2. Interaction of PDs with carbon nanostructures has been studied in ethanol and aqueous solutions for anionic (1), cationic (2), and neutral merocyanine (3) dyes

properties with functional molecules via the sorption, thus avoiding a cost-demanding chemical modification. The organic semiconducting functional composites based on NGs are promising materials for batteries, solar cells, photocapacitors, printed electronics, etc. $[6,7]$.

Polymethine dyes (PDs) are unique photo-energy convertors with the widest known range of photophysical properties $[8,9]$. This range can be even further extended in their nanocomposites, e.g., J-aggregates [10], formed both in solutions and on surfaces of various substrates, for example, silver halides, quantum dots, etc. [11]. Integration of PDs and carbon nanostructures promises new vistas for their application, in the first place as light-sensitive composites.

\section{Materials and Methods}

Preparative amounts of NG structures have been obtained by the electrochemical expansion of thermally expanded graphite in an acidic medium, followed by the transfer of the material filtered and washed out with water and ethanol into organic solvents with the subsequent sonication $(20 \mathrm{kHz})$ to form a homogeneous dispersion. This is one of the most promising ways of obtaining graphene and NG [12]. The resulting dispersions of $\mathrm{NG}$ in water, ethanol, and dioxane are stable in the concentration range $0-8 \mathrm{~g} / \mathrm{L}$; the average size of the multilayer graphene particles (or few-layer graphene) was $5 \times 5 \mu \mathrm{m}$ with a thickness of $50 \mathrm{~nm}$ (Fig. 1).

Some of the obtained NG underwent a chemical modification to increase the number of active groups on the surface capable of binding functional molecules. Thus, a suspension of NG (4 g) in $98 \%$ sulfuric acid $(100 \mathrm{~mL})$ was treated with potassium nitrate $(2 \mathrm{~g})$, persulfate $(4 \mathrm{~g})$, and permanganate $(8 \mathrm{~g})$ and stirred for $2 \mathrm{~h}$. Then the reaction mixture was heated to $50{ }^{\circ} \mathrm{C}$, sonicated $(20 \mathrm{kHz})$ for $30 \mathrm{~min}$, and poured into water $(900 \mathrm{~mL})$. To wash out the reaction product from the excess persulfate, which can intercalate into the graphite structure [13], and other reagents, the product was washed with water $(3 \times 30 \mathrm{~mL}), 0.5 \%$ hydrogen peroxide solution $(3 \times 30 \mathrm{~mL})$, and then again with water until neutral. The obtained brown substance was treated with cation-exchange resin KU-2-8 (100 g) in water; the precipitate was separated from the resin and washed with water until neutral to afford $2.8 \mathrm{~g}$ of the oxidized NG. The partial destruction of the conjugated $\pi$-system of NG during the oxidation was confirmed by UV-Vis spectroscopy. It was manifested by a decrease in the intensity of the $270-\mathrm{nm}$ absorption band characteristic of graphene [14]. The oxidized NG having active epoxy groups on the surface was further modified by treating its dioxane suspension with diethylamine. The product was repeatedly washed with dioxane and then with ethanol.

The interaction of PDs with carbon nanostructures has been studied in ethanol and aqueous solutions for anionic (1), cationic (2), and neutral merocyanine (3) dyes (Fig. 2), which were synthesized according to [15] 
and purified, by using column chromatography (silica gel $0.063-0.2 \mathrm{~mm}$, dichloromethane as an eluent) with TLC and the spectral (UV-Vis, ${ }^{1} \mathrm{H}$ NMR) control of the purity.

These compounds have intense selective absorption in the same spectral region and fluorescence with a small Stokes shift [8, 16, 17]. For dyes 2 and $\mathbf{3}$, the fluorescence quantum yield strongly depends on the medium viscosity, increasing by a factor of tens in solid matrices [8, 17], to which the surface of nanostructures can be parallelized. The studies were carried out in ethanol solutions at the 0.1$0.5 \mathrm{~g} / \mathrm{L}$-concentration of NGs and $(1-2) \times 10^{-6} \mathrm{~mol} / \mathrm{L}$ of dyes. Immediately before the addition of dyes, NG suspensions were treated for $10 \mathrm{~min}$ in an ultrasonic bath. The absorption spectra of solutions were recorded in 1-cm cells on a Shimadzu UV-3100 spectrophotometer, and fluorescence spectra were measured using a Solar CM2203 spectrofluorometer (Belarus).

\section{Results and Discussion}

It turned out that, with NGs unmodified, oxidized, and modified with diethylamine, the resulting absorption spectra are a superposition of the spectral curves of individual components (Fig. 3). This result indicates the absence of strong noncovalent interactions between dyes $\mathbf{1 - 3}$ and NGs in the studied systems.

Fluorescence spectroscopy is generally more sensitive than UV-Vis spectroscopy. However, in the present case, the intense scattering of the excitation light by nanoparticles of the non-modified NG has prevented registering the reliable fluorescence spectra even with polarization filters. Particulates of the chemically modified NG should be smaller, since the intercalation of reactants during the oxidation results in a further expansion of graphene layers. Consequently, the excitation light scattering should be less for them. Indeed, the fluorescence spectra have been registered for systems containing the oxidized NG (Fig. 4).

It has been found that the excitation in the nearUV spectrum region (320-400 nm) results in a very broad and structureless fluorescence band, which can be attributed as the fluorescence of the oxidized NG. Under the excitation in the region of $>500 \mathrm{~nm}$ (dyes' absorption bands), the narrow fluorescence band of a polymethine chromophore is dominating

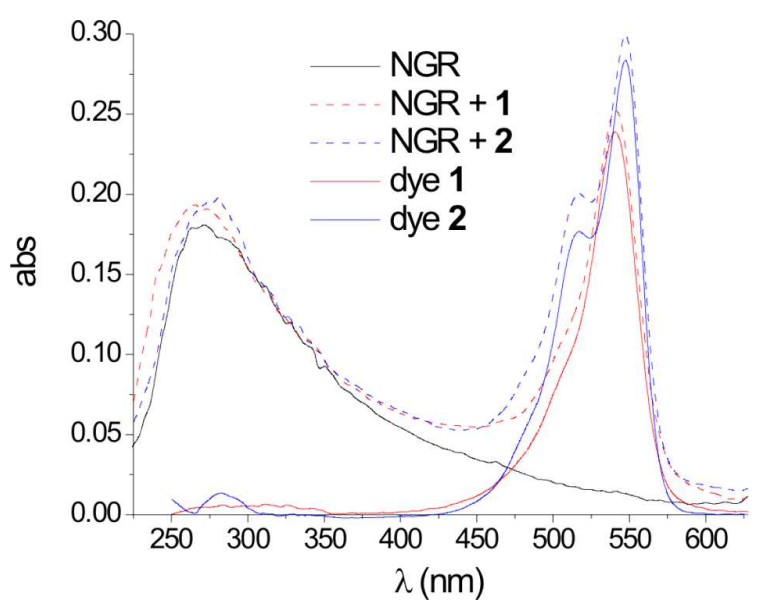

Fig. 3. UV-Vis spectra of the non-modified NG $(0.1 \mathrm{~g} / \mathrm{L})$, dyes $\mathbf{1}$ and $\mathbf{2}$, as well as their mixtures in ethanol

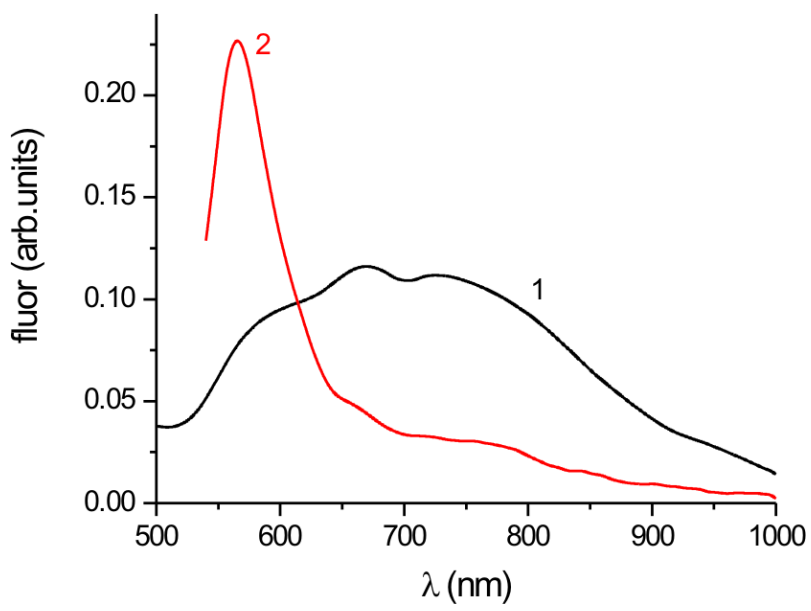

Fig. 4. Fluorescence spectra of the ethanol solution of the oxidized NG and dye 3: excitation at $390 \mathrm{~nm}$ (1), excitation at $500 \mathrm{~nm}$ (2)

(Fig. 4). At that, the intensity of the NG fluorescence band under the 500-nm excitation is almost the same as its intensity in the analogous solution of the pure oxidized NG. This means the marginal (or the absence of) dye-to-NG excitation energy transfer, i.e., the fluorescence measurements confirmed the conclusion made from the UV-Vis spectral data about their weak interaction.

Carbon nanotubes (CNTs) have much larger specific surface area than nanographite. Moreover, their inside cavity affords a highly polarized environment, which can host relatively small near-linear conjugated molecules [18]. This should favor their interaction with PDs. 

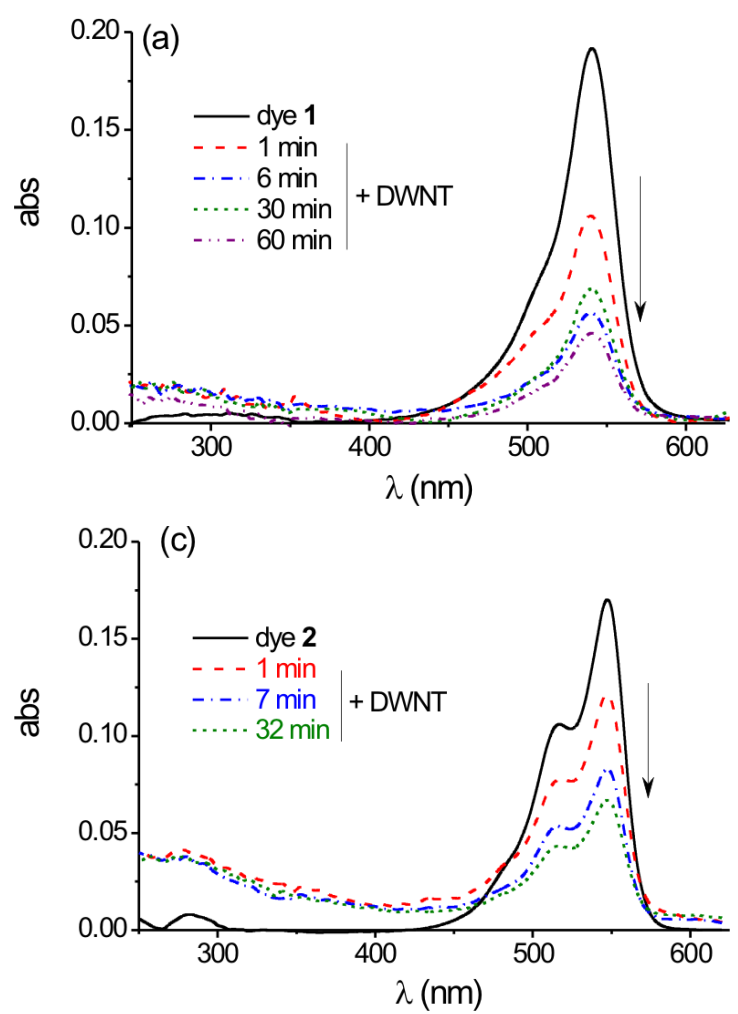
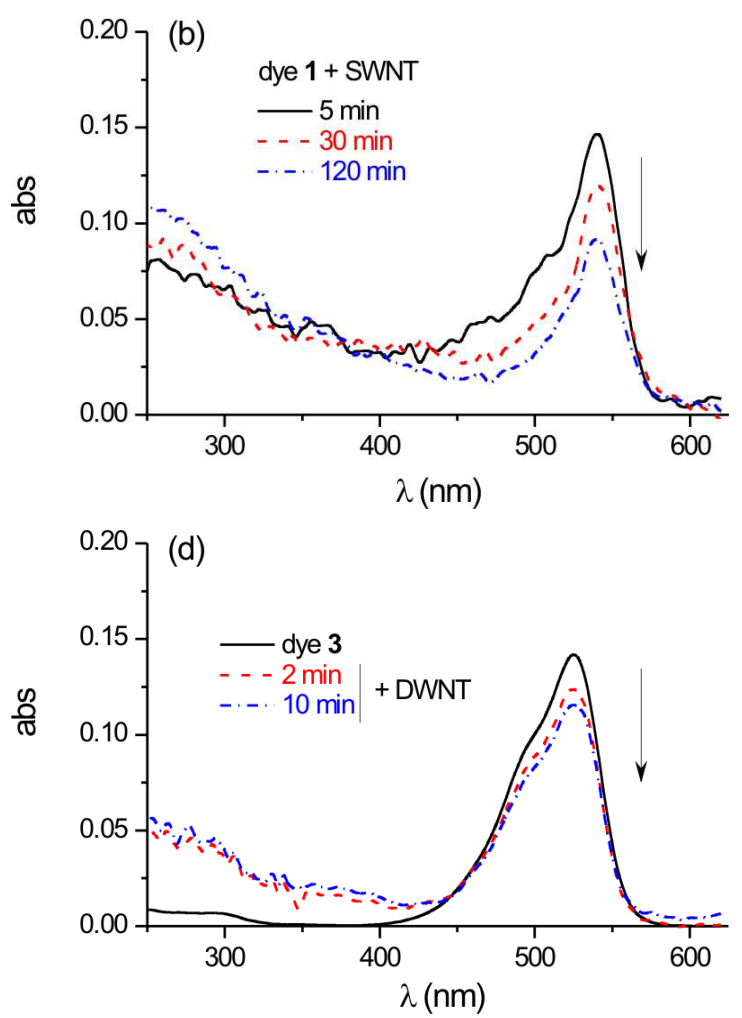

Fig. 5. UV-Vis absorption spectra of dyes $\mathbf{1}-\mathbf{3}$ in ethanol and their change in time after the addition of CNTs; $0.1 \mathrm{~g} / \mathrm{L}$ of DWNT $(a), 0.2 \mathrm{~g} / \mathrm{L}$ of CNTs $(b-d)$

It has been observed that the addition of CNTs, either single- (SWNT) or double- (DWNT) and multiwall (MWNT) ones, to the ethanol solutions of compounds $\mathbf{1}-\mathbf{3}$ results in a rapid decrease in the dye absorption intensity (Fig. 5). The saturation equilibrium for dye 1 is reached over $60-120 \mathrm{~min}$, depending on the type of CNTs.

Notably, in the case of DWNT and MWNT, the absorption intensity decrease is greater than with SWNT, i.e., more dye is bound per unit mass of the former (cf. Fig. 5, $a, b$ ). One can see also that the maximum effect is reached for anionic dye $\mathbf{1}$, it is slightly smaller for cationic dye $\mathbf{2}$, while it is much diminished for merocyanine $\mathbf{3}$.

There can be several reasons for the abated dyes' absorption here. The most obvious one is their photobleaching in the presence of CNTs. However, the studied dyes are derivatives of 1,3,3-trimethylindole and malononitrile, and both these terminal groups are known to provide a high photochemical stability to polymethines $[19,20]$. Moreover, no additional shortwavelength bands of the probable photodestruction products were detected, and the effects were observed in the closed cell holder of a spectrophotometer, i.e. in the absence of the intense ambient light. The formation of charge-transfer complexes between the dyes and CNTs also can be eliminated both due to the absence of any additional spectral bands and by the fact that the similar spectral changes were observed for dyes with three different charges of their chromophores.

Hence, it can be concluded that the observed spectral effects should be explained by the association of dyes with CNTs. There are two possible ways of their interaction, namely, the surface sorption and intercalation of dye molecules inside CNTs. We suppose that the latter is more probable in the case. Indeed, the studied dyes did not show any signs of interactions with the NGs, the surface of which is also well developed and, not unlike to the surface of CNTs, especially to the MWNT, that are characterized by the considerable outer diameter. There are some additional factors in favor of the intercalation mechanism: the maximum effects for anion $\mathbf{1}$ that is character- 
ized by the minimum width and thickness dimensions among the studied polymethines; the stronger effect for DWNT and MWNT in comparison with SWNT can be rationalized by the intercalation of dyes not only in the central cavity of CNT but also between the carbon layers; the literature data which unequivocally prove the possibility of such intercalation [18]. It should be mentioned, however, that this explanation does not reveal the actual physical mechanism of dye visual bleaching. We can only suppose that the light scattering on CNTs can be relevant here.

The interaction of dyes with CNTs is manifested not just in UV-Vis spectra. The resulting colloidal solutions with dyes $\mathbf{1}$ and $\mathbf{2}$ has been found more stable against the sedimentation, than the dispersion of pure CNTs. Probably, the dye ions binding to nanotubes provide them with like charge, thereby increasing their solubility in the polar medium and preventing their coalescence.

To get more insight into the interaction of carbon nanostructures with PDs, DFT/B3LYP/STO$3 \mathrm{G}$ quantum chemical simulations have been performed in the Gaussian-09 program package [21]. As a model of unmodified NG, an H-atoms-terminated graphene sheet $\mathrm{C}_{78} \mathrm{H}_{22}$ of symmetry $\mathrm{D}_{2 h}$ was build, its length exceeding the linear dimensions of the two investigated dyes. Oxidized graphene contains predominantly epoxy, hydroxyl, and carboxyl functional groups [22]. We did not introduce the first two, because this would have led to a violation of the aromaticity and planarity of the graphene sheet, by complexifying calculations dramatically. Hence, starting from the unmodified $\mathrm{C}_{78} \mathrm{H}_{22}$, a model graphene $\mathrm{C}_{86} \mathrm{H}_{22} \mathrm{O}_{16}$ was constructed with eight carboxyl groups on the rim. Their symmetric arrangement provided a high $\mathrm{D}_{2}$ symmetry of the molecule. For the same reason of maximum symmetry of the model systems, only dyes $\mathbf{1}$ and $\mathbf{2}$ were included in this study. It has been found that the interaction of both these dyes with the model graphene sheets is very weak: it does not exceed $23 \mathrm{~kJ} / \mathrm{mol}$ for the non-modified graphene $\mathrm{C}_{78} \mathrm{H}_{22}$ and $35 \mathrm{~kJ} / \mathrm{mol}$ for the model oxidized graphene $\mathrm{C}_{86} \mathrm{H}_{22} \mathrm{O}_{16}$ in the vacuum approximation and must be even less in solutions. This result conforms to the absence of a detectable interaction between dyes 1, 2 and the NGs.

The interaction of CNTs with small polar linear molecules is described in $[18,23]$. The main driv- ing factor here is the intercalation of molecules into the nanotube cavity. Such a model agrees with the changes in the nonlinear optical properties observed in the interaction with nanotubes of dipolar merocyanine molecules [18].

Modeling the CNTs is more difficult than modeling the graphene sheets. Even in the simplest case of SWNT, the problem of choosing an adequate model arises. Unlike single-layer graphene, there are dozens of isomeric SWNT, differing in diameter and chirality $[24,25]$. In a theoretical study, nanotubes are usually approximated by their short fragments containing 60-300 carbon atoms. In our case, the preliminary analysis showed that, to study the interaction of SWNT with cation 2, the length of a model fragment should be equal to $18-20 \AA$ at least. To simplify the calculation of the systems under study, it was necessary to choose an even non-chiral structure that would ensure the symmetry $\mathrm{C}_{2 v}$ for the model associates of CNTs with dyes $\mathbf{1}$ and $\mathbf{2}$. The chosen structure should preferably be a thermodynamically stable isomer. The analysis of the literature data [25] showed that only SWNTs (8.0) and (10.0) completely correspond to these criteria; for the (12.0) one, there exists a slightly more stable chiral isomer, while the chiral isomers become significantly more favorable for larger-diameter systems. For SWNT (8.0), the van der Waals diameter of the inner cavity was evaluated to be less than $4.0 \AA$, too small for the intercalation of the studied dye molecules, so they were not considered further.

Model SWNTs (10.0) and (12.0) were build by using the "Nanotube modeler" (JCrystalSoft), and then their DFT/B3LYP/STO-3G optimization was performed. The fragment of SWNT (10.0) of the formula $\mathrm{C}_{200} \mathrm{H}_{20}$ has a diameter of $8.6 \AA$ by the C-atom centers, but the parameter determining its properties as the "host" in the inclusion structures is the van der Waals size of its internal cavity. Taking into account that the van der Waals radius of a carbon atom is ca. $1.7 \AA$, the latter value is equal to $5.2 \AA$. The maximum breadths of molecules $\mathbf{1}$ and $\mathbf{2}$ are equal to $6.2 \AA$ and $8.2 \AA$, correspondingly, both exceeding the above value. For the model SWNT (12.0), the van der Waals size of its inner cavity was estimated as $7.1 \AA$, still less than the size of the molecule 2 .

We further studied the following systems: [SWNT (10.0) + anion 1], [SWNT (12.0) + anion 1], and [SWNT (12.0) + cation 2]; the geometry optimiza- 
tions were performed with the dye molecules placed inside the corresponding model nanotube. It has been found that, in all three cases, the final energy of the system is smaller than the total energy of the individual components. The maximum stabilization $(67 \mathrm{~kJ} / \mathrm{mol})$ is achieved for the complexes [SWNT $(12.0)+$ anion $\mathbf{1}$ ] and [SWNT (12.0) + cation 2]. The analysis of the geometries of the final structures has shown that, in cases where the cavity of an isolated nanotube is slightly smaller than the size of a guest molecule, a small elliptical deformation of the nanotube takes place. The resulting stabilization of the studied systems indicates that the energy required for this deformation is smaller than the energy of interaction of the dye with the nanotube. Hence, the calculations have shown that CNTs can more effectively, than NGs, bind dye molecules, incorporating them into the internal cavity. Note also that the average diameter of industrially available SWNTs is $1-1.5 \mathrm{~nm}$ $[3,25]$, i.e., even greater than in the chosen model structures.

\section{Conclusions}

A simple technique affording the preparation of macroscopic amounts of nanographite (tens of grams) from the available starting material has been implemented. The chemical functionalization of the obtained NG has been carried out in order to modify its binding properties. Stable suspensions of NG and its modifications are obtained in water and organic solvents. It is found that cationic, anionic, and merocyanine polymethine dyes do not bind efficiently with the surface of the NGs under study in ethanol solutions. Carbon nanotubes of different types (single-, double-, and multiwall) under the same conditions form stable associates with polymethine dyes, which is primarily manifested by a decrease in the intensity of dye's absorption in time, as well as by the additional stabilization of the nanotube suspension in the case of ionic polymethines. The performed DFT calculations demonstrate that the studied dyes, indeed, do not bind strongly with NGs, though they can enter the inner cavity of CNTs, thus forming more stable aggregates.

1. K.S. Novoselov, A.K. Geim, S.V. Morozov, D. Jiang, Y. Zhang, S.V. Dubonos, I.V. Grigorieva, A.A. Firsov. Electric field effect in atomically thin carbon films. Science 306 (5696), 666 (2004).

\section{4}

2. N. Komatsu, N. Kadota, T. Kimura, Y. Kikuchi, M. Arikawa. Remarkable improvement in efficiency of filtration method for fullerene purification. Fullerenes, Nanotubes, Carbon Nanostruct. 15, 217 (2007).

3. M.C. Hersam. Progress towards monodisperse singlewalled carbon nanotubes. Nat. Nanotechnol. 3, 387 (2008).

4. G. Ning, T. Li, J. Yan, C. Xu, T. Wei, Z. Fan. Threedimensional hybrid materials of fish scale-like polyaniline nanosheet arrays on graphene oxide and carbon nanotube for high-performance ultracapacitors. Carbon 54, 241 (2013).

5. K. Kusakabe, M. Maruyama. Magnetic nanographite. Phys. Rev. B 67, 092406 (2003).

6. X. Huang, X. Qi, F. Boey, H. Zhang. Graphene-based composites. Chem. Soc. Rev. 41, 666 (2012).

7. M.F.L. De Volder, S.H. Tawfick, R.H. Baughman, A.J. Hart. Carbon nanotubes: present and future commercial applications. Science 339 (6119), 535 (2013).

8. A.A. Ishchenko. Structure and spectral-luminescent properties of polymethine dyes. Russ. Chem. Rev. 60, 865 (1991).

9. A. Mishra, R.K. Behera, P.K. Behera, B.K. Mishra, G.B. Behera. Cyanines during the 1990s: A review. Chem. Rev. 100, 1973 (2000).

10. F. Würthner, T.E. Kaiser, C.R. Saha-Möller. J-aggregates: From serendipitous discovery to supramolecular engineering of functional dye materials. Angew. Chem. Int. Ed. 50, 3376 (2011).

11. N.N. Ledentsov, V.M. Ustinov, V.A. Shchukin, P.S. Kop'ev, Zh.I. Alferov. Quantum dot heterostructures: Fabrication, properties, lasers (Review). Semiconductors 32, 343 (1998).

12. Z.Y. Xia, S. Pezzini, E. Treossi, G. Giambastiani, F. Corticelli, V. Morandi, A. Zanelli, V. Bellani, V. Palermo. The exfoliation of graphene in liquids by electrochemical, chemical, and sonication-assisted techniques: A nanoscale study. Adv. Funct. Mater. 23, 4684 (2013).

13. A.V. Melezhyk, A.G. Tkachev. Synthesis of graphene nanoplatelets from peroxosulfate graphite intercalation compounds. Nanosystems: Phys. Chem. Math. 5, 294 (2014).

14. K.F. Mak, L. Ju, F. Wang, T.F. Heinz. Optical spectroscopy of graphene: From the far infrared to the ultraviolet. Solid State Commun. 152, 1341 (2012).

15. Chemistry of Heterocyclic Compounds. Vol. 18. The Cyanine Dyes and Related Compounds. Edited by F.M. Hamer (Wiley, 1964) [ISBN: 9780470381816].

16. A.V. Kulinich, N.A. Derevyanko, A.A. Ishchenko. Synthesis and spectral properties of malononitrile-based merocyanine dyes. Russ. Chem. Bull. 54, 2820 (2005).

17. A.A. Ishchenko, A.V. Kulinich, S.L. Bondarev, V.N. Knyukshto. Electronic structure and fluorescent properties of malononitrile-based merocyanines with positive and negative solvatochromism. Optics Spectrosc. 104, 57 (2008).

ISSN 2071-0194. Ukr. J. Phys. 2018. Vol. 63, No. 5 
18. S. Cambré, J. Campo, C. Beirnaert, C. Verlackt, P. Cool, W. Wenseleers. Asymmetric dyes align inside carbon nanotubes to yield a large nonlinear optical response. Nat. Nanotechnol. 10, 248 (2015).

19. C.J. MacNevin, D. Gremyachinskiy, C.-W. Hsu, L. Li, M. Rougie, T.T. Davis, K.M. Hahn. Environment-sensing merocyanine dyes for live cell imaging applications. Bioconjugate Chem. 24, 215 (2013).

20. A.V. Kulinich, A.A. Ishchenko, A.K. Chibisov, G.V. Zakharova. Effect of electronic asymmetry and the polymethine chain length on photoprocesses in merocyanine dyes. J. Photochem. Photobiol. A 91, 274 (2014).

21. M.J. Frisch, G.W. Trucks, H.B. Schlegel, G.E. Scuseria, M.A. Robb, J.R. Cheeseman, G. Scalmani, V. Barone, G.A. Petersson, H. Nakatsuji, X. Li, M. Caricato, A. Marenich, J. Bloino, B.G. Janesko et al. Gaussian 09, Rev. D.01 (Gaussian, Inc., 2009).

22. D. Pandey, R. Reifenberger, R. Piner. Scanning probe microscopy study of exfoliated oxidized graphene sheets. Surf. Sci. 602, 1607 (2008).

23. P. Lutsyk, R. Arif, J. Hruby, A. Bukivskyi, O. Vinijchuk, M. Shandura, V. Yakubovskyi, Y. Kovtun, G.A. Rance, M. Fay, Y. Piryatinski, O. Kachkovsky, A. Verbitsky, A. Rozhin. A sensing mechanism for the detection of carbon nanotubes using selective photoluminescent probes based on ionic complexes with organic dyes. Light Sci. Appl. 5, e16028 (2016).

24. P.A. Gowrisankar, K. Udhayakumar. Electronic properties of boron and silicon doped $(10,0)$ zigzag singlewalled carbon nanotube upon gas molecular adsorption: a DFT comparative study. J. Nanomater. 2013, 293936 (2013).
25. D. Hedman, H. Reza Barzegar, A. Rosén, T. Wågberg, J.A. Larsson. On the stability and abundance of single walled carbon nanotubes. Sci. Rep. 5, 16850 (2015).

Received 15.01 .18

А.В. Кулініч, О.О. Іщенко,

Л.Ф. Шаранда, С.В.Шулъга, В.М. Огенко

СОРБЦІЯ ПОЛІМЕТИНОВИХ

БАРВНИКІВ НА НАНОГРАФІТАХ

ТА ВУГЛЕЦЕВИХ НАНОТРУБКАХ

Р е з ю м е

Сорбція функціональних молекул - простий і досить ефективний спосіб модифікації наноструктур. Метою цієї роботи було вивчення сорбції поліметинових барвників різної йонності на нанографітах і вуглецевих нанотрубках. Впроваджено просту методику отримання макроскопічних кількостей нанографіту (десятки грамів) з доступного вихідного матеріалу. Виконана хімічна функціоналізація отриманого нанографіту з метою варіювання його зв'язуючих властивостей. Отримані стабільні суспензії нанографіту і його модифікованих форм у воді і органічних розчинниках. Виявлено, що катіонні, аніонні і нейтральні (мероціаніни) поліметинові барвники неефективно сорбуються поверхнею досліджуваних нанографітів. Вуглецеві нанотрубки різних типів (одно-, дво- і багатостінні) за тих самих умов утворюють стійкі асоціати з поліметиновими барвниками, що в першу чергу проявляється в зменшенні інтенсивності поглинання барвників у часі, а також у додатковій стабілізації суспензії нанотрубок. Розрахунки DFT показують, що вивчені барвники дійсно не схильні зв'язуватися з нанографітами, але можуть утворювати більш стабільні агрегати 3 вуглецевими нанотрубками. 